Creative Commons User License: CC BY-NC-ND

Abstracted by: EBSCOhost, Electronic Journals Service (EJS),

Google Scholar, Journal Seek, Scientific Commons,

Food and Agricultural Organization (FAO), CABI and Scopus

http://eoi.citefactor.org/10.11226/v24i4
Journal of Agricultural Extension

Vol. 24 (4) October, 2020

ISSN(e): 24086851; ISSN(Print); 1119944X

http://journal.aesonnigeria.org

http://www.ajol.info/index.php/jae

Email: editorinchief@aesonnigeria.org

\title{
Adoption of Good Agricultural Practices by Cattle Farmers in the Binh Dinh Province of Vietnam
}

https://dx.doi.org/10.4314/jae.v24i4.15

\author{
Hoang, Gia Hung \\ University of Agriculture and Forestry \\ Hue University, Vietnam \\ Email: hghung@hueuni.edu.vn \\ +840899878951
}

\section{Abstract}

This study examined factors that affect the adoption of good agricultural practices (VietGAP) by Vietnamese beef cattle farmers. A random sample of 305 farmers was drawn from a total of 1279 farmers who produced and marketed beef cattle in the Binh Dinh province of Vietnam. Percentages, means, standard deviations, chi squares test, t-test and binary logistic regression model were employed to analyse the data. The study found that the young farmers with a higher education level, who had a large number of cattle, possessed a large farm, owned ICT tools for marketing, participated in credit and training programs, had a high income and communicated with extension officers, had a greater tendency to adopt VietGAP. Improving education, providing technical training and credit services, promoting the farmers' use of ICT tools for marketing and developing agricultural extension services for livestock farmers is a way to facilitate the adoption of VietGAP by farmers.

Key words: beef cattle farmers, ICT, adoption, VietGAP, Binh Dinh Province.

\section{Introduction}

Livestock plays an important role in rural livelihoods and economic development in developing countries. It has been providing the main employment and income for the majority of farmers (Sarkar, 2020). However, livestock farmers, including beef cattle farmers in developing nations, such as Vietnam, are facing difficulties in participating in markets due to the introduction of food standards such as Good Agricultural Practices. Good agricultural practices (GAP) was first developed by a group of European retailers to co-ordinate food quality and safety standards (Annor, MensahBonsu, \& Jatoe, 2016) and to respond to consumers' concerns on food safety (Lippe \& Grote, 2016). The standard was named EurepGAP and it has been accepted as the common food retail standard for the European markets. In 2007, EurepGAP was re-named GlobalGAP to reflect its growing use by countries outside Europe ${ }^{1}$. GlobalGAP is now widely known as a private food standard internationally (Annor et al., 2016). Besides GlobalGAP, governments in some countries have also developed and introduced their own GAPs that are based on GlobalGAP. This type of GAP is referred to as a public GAP. Examples of public GAPs include: Q-GAP in Thailand (Krause, Lippe, \& Grote, 2016; Wongprawmas, Canavari, \& Waisarayutt, 2015),

\footnotetext{
${ }^{1}$ : See www.eurepgap.org and www.globalgap.org for the history of EurepGAP and GlobalGAP.
} 
Creative Commons User License: CC BY-NC-ND

Abstracted by: EBSCOhost, Electronic Journals Service (EJS), Google Scholar, Journal Seek, Scientific Commons,

Food and Agricultural Organization (FAO), CABI and Scopus
Journal of Agricultural Extension

Vol. 24 (4) October, 2020

ISSN(e): 24086851; ISSN(Print); 1119944X

http://journal.aesonnigeria.org

http://www.ajol.info/index.php/jae

Email: editorinchief@aesonnigeria.org

MyGAP in Malaysia (Amekawa, Ng, Lumayag, Tan, Wong, Abdulrauf, Tan, Tai, Tan, \& Liu, 2017) and VietGAP in Vietnam (Loan, Pabuayon, Catelo, \& Sumalde, 2016).

VietGAP was introduced in 2008 to farmers, and contains the rules, orders and procedures that guide farmers to produce, process and market agricultural produce to meet a number of requirements (Loan et al., 2016). These include the requirements relating to food safety and quality, product traceability and environmental protection (Vu Thi, Nguyen Mau, \& Santi, 2016). VietGAP has also been applied to livestock. However, adoption of VietGAP by Vietnamese livestock farmers is not well documented. The Government of Vietnam has strongly promoted the adoption of VietGAP for facilitating the country's sustainable agricultural development over the past decade (Rural and Agriculture Census, 2016). However, the adoption of VietGAP by Vietnamese livestock farmers is still very limited. If we understand key factors that affect the farmers' adoption of VietGAP, then it is possible to facilitate the famers' uptake of VietGAP and this will help facilitate changes and sustainable development for Vietnamese livestock farmers.

Literature (Annor et al., 2016; Loan et al., 2016; Nguyen, Nanseki, \& Chomei, 2019; Vu Thi et al., 2016) shows that adoption of GAP by farmers is likely to be associated with either one, or some, of the following factors: (1) factors related to the farmers such as age and education level (Krause et al., 2016; Lippe \& Grote, 2016); (2) characteristics of farms such as farm size and income (Annor et al., 2016; Loan et al., 2016); and (3) aspects related to the level of support given to farmers under GAP programmes such as technical training (Lippe \& Grote, 2016). However, a few studies have investigated the combination of the mentioned factors about the farmers' adoption of VietGAP. In addition, there is no known study that has investigated determinants of the adoption of VietGAP by beef cattle farmers. Moreover, the findings reported in the mainstream literature (Annor et al., 2016; Loan et al., 2016; Nguyen et al., 2019; Vu Thi et al., 2016) are not consistent across the studies. The aim of this research was to examine factors that affect the adoption of VietGAP by Vietnamese beef cattle farmers.

The specific objectives of this research were to:

(1) describe characteristics of Vietnamese beef cattle farmers;

(2) define the farmers' awareness of VietGAP in farming beef cattle; and

(3) determine factors that associate with farmers' adoption of VietGAP.

\section{Methodology}

This study was conducted in the Binh Dinh province of Vietnam, which lies between 13.39 to 14.42 north latitude and 158.54 to 108.55 east longitude. The province comprises 6,066.2 km² (606,620 ha) (Binh Dinh Statistical Office, 2020). The agricultural sector made up about $30 \%$ of the gross output of the province in 2019. More than $70 \%$ of the population live in rural areas and are engaged in agricultural activities (Binh Dinh Statistical Office, 2020). The agricultural sector in the province comprises livestock and cropping activities, but beef cattle production is the most important contributor to agricultural activity and, hence, a focus for the development in the province. 
Creative Commons User License: CC BY-NC-ND

Abstracted by: EBSCOhost, Electronic Journals Service (EJS), Google Scholar, Journal Seek, Scientific Commons,

Food and Agricultural Organization (FAO), CABI and Scopus
Journal of Agricultural Extension

Vol. 24 (4) October, 2020

ISSN(e): 24086851; ISSN(Print); 1119944X

http://journal.aesonnigeria.org

http://www.ajol.info/index.php/jae

Email: editorinchief@aesonnigeria.org

A sample size of 305 beef cattle farmers were determined based on the $95 \%$ confidence level and a margin of error of 5\% from 1279 total farmers who mainly produced and marketed beef cattle in the Binh Dinh province, using the sample determination formula described in the literature (Laaksonen, 2018). The total population of 1279 beef cattle farmers is in the list of households of the province, which is obtained from the office of Binh Dinh Province People's Committee. A twopart structured questionnaire was developed to collect data. The first part comprised 12 statements on VietGAP requirements such as: farming beef cattle conforming to VietGAP requires (1) vaccinating cattle; (2) treating wastes daily to protect environment; (3) using hygiene facilities to ensure food safety; (4) putting cattle cages in the right position to protect environment; and (5) choosing breeding from clear sources to ensure product traceability. The statements were measured on "yes" and "no" choices. The second part gathered demographic and socio-economic information. The questionnaire was pre-tested with 15 farmers and reviewed by a panel of experts for face and content validity. Fifteen trained enumerators were hired to manage the questionnaires in the field. The survey was conducted from February to April, 2020. Data were analysed in IBM-SPSS Statistics version 20, and percentages, means and standard deviations were used. Inferential statistics such as Chi squares test for dummy variables by farmers' adoption of VietGAP and T-test for continuous variables were applied to identify the relationships between independent variables associated with the adoption of VietGAP by farmers. Multicollinearity among the variables was checked. A binary logistic regression model was used to determine the effect of the independent variables on the dependent variable (Mukherjee, Sinha, \& Chatterjee, 2018). The dependent variable is a dummy variable which takes a value of 1 for the VietGAP adopter and 0 otherwise. Table 1 describes the characteristics of hypothesized dependent and independent variables in the VietGAP adoption. 
Creative Commons User License: CC BY-NC-ND

Abstracted by: EBSCOhost, Electronic Journals Service (EJS), Google Scholar, Journal Seek, Scientific Commons,

Food and Agricultural Organization (FAO), CABI and Scopus

http://eoi.citefactor.org/10.11226/v24i4
Journal of Agricultural Extension

Vol. 24 (4) October, 2020

ISSN(e): 24086851; ISSN(Print); 1119944X

http://journal.aesonnigeria.org

http://www.ajol.info/index.php/jae

Email: editorinchief@aesonnigeria.org

Table 1. Hypothesized variables in the VietGAP adoption

\begin{tabular}{|c|c|c|c|}
\hline Variables & Category & Measurement & $\begin{array}{l}\text { Expected } \\
\text { effect }\end{array}$ \\
\hline \multicolumn{4}{|c|}{ Dependent variable } \\
\hline Adoption of VietGAP & Dummy & $\begin{array}{c}1 \text { = adopters; } \\
0=\text { non-adopter }\end{array}$ & \\
\hline \multicolumn{4}{|c|}{ Independent variables } \\
\hline Age of farmers & Continuous & Years $^{a}$ & $+/-$ \\
\hline Gender of farmers & Dummy & $\begin{array}{l}1=\text { male } ; 0= \\
\text { female }\end{array}$ & $+/-$ \\
\hline Education level of farmers & Continuous & Years $^{b}$ & + \\
\hline Family (household) size & Continuous & Numeric & + \\
\hline Experience in farming & Continuous & Years $^{c}$ & + \\
\hline Number of cattle owned & Continuous & Numeric & $+/-$ \\
\hline Distance from markets & Continuous & Kilometres & $+/-$ \\
\hline Farm size & Continuous & $\mathrm{Sao}^{\mathrm{d}}$ & + \\
\hline Total annual income $e^{e}$ & Continuous & $V_{N} D^{f}$ & + \\
\hline $\begin{array}{l}\text { Participation in training } \\
\text { programs }\end{array}$ & Dummy & $1=$ yes $; 0=$ no & + \\
\hline Participation in credit programs & Dummy & $1=$ yes $; 0=$ no & + \\
\hline $\begin{array}{l}\text { Participation in community- } \\
\text { based organisations (CBOs) }\end{array}$ & Dummy & $1=$ yes $; 0=$ no & + \\
\hline Extension contact & Dummy & $1=$ yes $; 0=$ no & + \\
\hline Owning $\mathrm{ICT}^{\mathrm{g}}$ for marketing & Dummy & $1=$ yes $; 0=$ no & + \\
\hline
\end{tabular}

Note:

a: $1=18-24$ years old $; 2=25-34 ; 3=35-44 ; 4=45-54 ; 5=55-64 ; 6=65$ years old or older.

b: 1 = did not go to school; 2 = primary school; 3 =junior high school; $4=$ senior high school; $5=$ certificates; $6=$ university degree; 7 = postgraduate.

c: $1=1-2$ years; $2=3-5 ; 3=6-8 ; 4=9-11 ; 5=12-15 ; 6=16-19 ; 7=20-24 ; 8=25-28 ; 9=29-32 ; 10=33$ or higher.

d: one hectare equals to 20 sao.

e: 1 = nil; 2 = 1-30 VND million; 3 = 31-45; 4 = 46-60; 5 = 61-75; 6 = 76-80; 7 = 81-95; 8 = 96-115; 9 = 116-130; $10=131-145$;

$11=146-160 ; 12=161-180 ; 13=181-200 ; 14=201-220 ; 15=221-240 ; 16=241$ or higher.

$\mathrm{f}$ : VND is Vietnamese dong. About 23.000 VND = 1 USD.

$\mathrm{g}$ : information and communication technologies (ICT).

\section{Results and Discussion}

\section{Characteristics of Beef Cattle Farmers}

Table 2 describes the main characteristics of beef cattle farmers participating in this research. The farmers' average experience in farming was from 12-15 years. On average, a household owned 2.1 cattle. The average distance from farmers' homes 
Creative Commons User License: CC BY-NC-ND

Abstracted by: EBSCOhost, Electronic Journals Service (EJS), Google Scholar, Journal Seek, Scientific Commons,

Food and Agricultural Organization (FAO), CABI and Scopus
Journal of Agricultural Extension

Vol. 24 (4) October, 2020

ISSN(e): 24086851; ISSN(Print); 1119944X

http://journal.aesonnigeria.org

http://www.ajol.info/index.php/jae

Email: editorinchief@aesonnigeria.org

to the nearest local markets was about three kilometres. The average size of farmland owned by a farmer was 9.6 sao ("sao" is a common unit of land area in Vietnam and one "sao" equals to $500 \mathrm{~m}^{2}$ ). The annual average income of the farmers was from $76-80$ VND million. The percentage $(55.1 \%)$ of the farmers who participated in training courses was higher than those who did not take part $(44.9 \%)$. In contrast, the proportion $(28.5 \%)$ of the farmers who took part in credit programs was less than those who did not participate $(71.5 \%)$. The proportion $(78.0 \%)$ of the farmers who were members of CBOs was greater than those who did not take part in this type of community-based organisation (22.0\%). The proportion (79.7\%) of the farmers who had contact with agricultural extension workers was higher than those who had no communication with the agricultural extension workers (20.3\%). There were high percentage $(83.6 \%)$ of farmers who owned ICT tools for marketing compared with those who did not possess the ICT tools (16.4\%). Results of this study show that the characteristics of Vietnamese beef cattle farmers vary, reflecting diverse farming systems. Some of the previous research (Hoang, 2020; Pedroso, Tran, Nguyen, Le, Ribbe, Dang, \& Le, 2017) indicate that the characteristics of Vietnamese farmers vary and the majority of the Vietnamese farmers operate in small-scale farming, which is corroborated by the results of this research.

Table 2: Characteristics of farmers

\begin{tabular}{|c|c|c|}
\hline Characteristics & Percentage (\%) & Mean \\
\hline Age in years & - & 4.0 \\
\hline \multicolumn{3}{|l|}{ Sex } \\
\hline Male & 50.2 & - \\
\hline Female & 49.8 & - \\
\hline \multicolumn{3}{|l|}{ Educational level } \\
\hline Did not go to school & 1.6 & - \\
\hline Primary school & 17.7 & - \\
\hline Junior high school & 57.7 & - \\
\hline Senior high school & 20.3 & - \\
\hline Certificates & 1.6 & - \\
\hline University degree & 0.7 & - \\
\hline Postgraduates & 0.3 & - \\
\hline Experience in farming (years) & - & 5.3 \\
\hline Number of cattle owned & - & 2.1 \\
\hline Distance from markets $(\mathrm{km})$ & - & 2.9 \\
\hline Farm size (sao) & - & 9.6 \\
\hline Income/year (VND million) & - & 6.2 \\
\hline Participated in training course & 55.1 & - \\
\hline Participated in credit program & 28.5 & - \\
\hline Participated in Community Based Organisations (CBO) & 78.0 & - \\
\hline Extension contact & 79.7 & - \\
\hline Own ICT tools for marketing & 83.6 & - \\
\hline
\end{tabular}

Source: Field survey, 2020 
Creative Commons User License: CC BY-NC-ND

Abstracted by: EBSCOhost, Electronic Journals Service (EJS),

Google Scholar, Journal Seek, Scientific Commons,

Food and Agricultural Organization (FAO), CABI and Scopus
Journal of Agricultural Extension

Vol. 24 (4) October, 2020

ISSN(e): 24086851; ISSN(Print); 1119944X

http://journal.aesonnigeria.org

http://www.ajol.info/index.php/jae

Email: editorinchief@aesonnigeria.org

\section{Farmers' Awareness of Beef Cattle Farming Conforming to VietGAP}

Table 3 reports farmers' awareness of farming beef cattle conforming to VietGAP in the study region. A high proportion of the beef cattle farmers indicated conforming to VietGAP standard as follows: vaccinating cattle $(99.7 \%)$, followed by treating wastes daily to protect environment $(97.7 \%)$, using hygiene facilities to ensure food safety $(97.4 \%)$, putting cattle cages in the right position to protect environment $(94.8 \%)$, choosing breeding from clear sources to ensure product traceability $(91.5 \%)$, checking drinking water for cattle to ensure food quality $(90.8 \%)$, frequent sterilization of cattle cages to ensure food safety (88.9\%), and checking forages for cattle to ensure food quality (88.2\%). However, to a lesser extent, some requirements of VietGAP including: record keeping to ensure product traceability $(51.5 \%)$, having sufficient labouring protection equipment $(69.2 \%)$ and, followed the right technical process of VietGAP (69.7\%) were also identified as requirements of VietGAP when farming beef cattle. Beef cattle farmers were well aware of most of the farming methods conforming to VietGAP. Although, some studies (Loan et al., 2016; Nguyen et al., 2019; Vu Thi et al., 2016) have looked at VietGAP adoption by farmers, only few information exist about farmers' awareness of VietGAP requirements when farming conforming to VietGAP.

Table 3: Farmers' awareness of beef cattle farming conforming to VietGAP

\begin{tabular}{lc}
\hline \multicolumn{1}{c}{$\begin{array}{c}\text { Statements on farming beef cattle conforming to VietGAP } \\
\text { requirements }\end{array}$} & $\begin{array}{c}\text { Percentages } \\
\text { (\%) }\end{array}$ \\
\hline Vaccinating cattle & 99.7 \\
Treating wastes daily to protect environment & 97.7 \\
Using hygiene facilities to ensure food safety & 97.4 \\
Putting cattle cages in the right position to protect environment & 94.8 \\
Choosing breeding from clear sources to ensure product traceability & 91.5 \\
Checking drinking water for cattle for food safety & 90.8 \\
Frequent sterilization of cattle cages & 88.9 \\
Checking forages for cattle to ensure food quality & 88.2 \\
Using right antibiotics for cattle to ensure food safety & 70.5 \\
Following right technical process of VietGAP & 69.5 \\
Owning sufficient labouring protection equipment & 69.2 \\
Record keeping to ensure product traceability & 51.5 \\
\hline
\end{tabular}

Source: Field survey, 2020

\section{Factors Associated with Farmers' Adoption of VietGAP}

Table 4 shows that the beef cattle farmers' adoption of VietGAP was positively and statistically associated with their ICT ownership $(\beta=2.895 ; p \leq 0.05)$ and extension contact $(\beta=1.016, p \leq 0.05)$. This means that the farmers who owned ICT tools for 
Creative Commons User License: CC BY-NC-ND

Abstracted by: EBSCOhost, Electronic Journals Service (EJS), Google Scholar, Journal Seek, Scientific Commons,

Food and Agricultural Organization (FAO), CABI and Scopus
Journal of Agricultural Extension

Vol. 24 (4) October, 2020

ISSN(e): 24086851; ISSN(Print); 1119944X

http://journal.aesonnigeria.org

http://www.ajol.info/index.php/jae

Email: editorinchief@aesonnigeria.org

marketing and who had communication with agricultural extension workers, tend to be VietGAP adopters. In the mainstream literature (Loan et al., 2016; Nguyen et al., 2019; Srisopaporn, Jourdain, Perret, \& Shivakoti, 2015; Vu Thi et al., 2016) the importance of possessing ICT tools for marketing and its impact on farmers' adoption of public GAP has rarely been discussed.

The study found that beef cattle farmers' adoption of VietGAP was positively and statistically associated with their participation in credit programs $(\beta=0.694 ; p \leq$ $0.05)$, which suggests that the farmers who participated in credit programs are in a better position to adopt VietGAP than those who did not take part in these programs. Although some scholars (Annor et al., 2016) have mentioned the importance of access to credit and its impact on farmers' adoption of GAP, the finding from this research has not been reported in previous studies. The study also found that beef cattle farmers' adoption of VietGAP was positively and statistically associated with their participation in training programs $(\beta=0.771$; $p \leq 0.05)$, which means that the farmers who participated in training programs are in a better position to adopt VietGAP than those who did not take part. In a study by Nguyen et al. (2019), the authors report that training was a factor that positively contributed to the adoption of VietGAP by pig farmers, which is corroborated by the results of this research.

It was found that beef cattle farmers' adoption of VietGAP was positively and statistically associated with their income $(\beta=0.111 ; p \leq 0.05)$ and farm size $(\beta=$ 0.068; $p \leq 0.05$ ), which implies that the farmers who had a high income and who owned a large farm are in a better position to adopt VietGAP than those who had a lower income and possessed a small farm. Basically, the results of this research are consistent with findings reported in the literature (Annor et al., 2016; Loan et al., 2016), that income positively influenced farmers' decisions to adopt GlobalGAP. It was also found that adoption of VietGAP was positively affected by the number of cattle owned by a farmer $(\beta=0.417 ; p \leq 0.05)$, which means that the farmers who had a large number of cattle tended to be VietGAP adopters. The adoption of VietGAP was positively influenced by farmers' education level ( $\beta=0.476 ; p \leq 0.05)$. This suggests that farmers who have a higher education level are in a better position to adopt VietGAP than farmers with a lower level of education. Lippe and Grote (2016) found that Thai farmers are more likely to adopt GlobalGAP if they are better educated, which is supported by the results of this research. The present study found that beef cattle farmers' adoption of VietGAP was negatively associated with their age $(\beta=-0.318 ; p \leq 0.05)$, which means that younger farmers tend to be VietGAP adopters. In a study by Loan et al. (2016) the authors found that there was a negative relationship between fruit farmers' adoption of VietGAP and their age, but it was not statistically significant, which is supported by the results of this research. 
Creative Commons User License: CC BY-NC-ND

Abstracted by: EBSCOhost, Electronic Journals Service (EJS),

Google Scholar, Journal Seek, Scientific Commons,

Food and Agricultural Organization (FAO), CABI and Scopus

http://eoi.citefactor.org/10.11226/v24i4
Journal of Agricultural Extension

Vol. 24 (4) October, 2020

ISSN(e): 24086851; ISSN(Print); 1119944X

http://journal.aesonnigeria.org

http://www.ajol.info/index.php/jae

Email: editorinchief@aesonnigeria.org

Table 4: Association between farmers' characteristics and adoption of VietGAP

\begin{tabular}{lcc}
\hline Variables & Coefficient $(\boldsymbol{\beta})$ & Std. Err. \\
\hline Age & $-0.318^{\star *}$ & 0.142 \\
Gender & 0.600 & 0.314 \\
Level of education & $0.476^{\star *}$ & 0.197 \\
Family size & -0.142 & 0.136 \\
Farming experience & 0.114 & 0.077 \\
Number of cattle owned & $0.417^{\star *}$ & 0.204 \\
Distance from markets & 0.016 & 0.099 \\
Farm size & $0.068^{\star *}$ & 0.031 \\
Income & $0.111^{\star *}$ & 0.049 \\
Participation in training & $0.771^{\star *}$ & 0.335 \\
course & & \\
Participation in credit & $0.694^{* *}$ & 0.348 \\
program & & \\
Participation in community & -0.083 & 0.515 \\
based organisations (CBO) & $1.016^{\star *}$ & 0.503 \\
Extension contact & $2.895^{\star *}$ & 1.047 \\
ICT ownership & -7.800 & 1.697 \\
Constant & &
\end{tabular}

Note: Number of observations $=305$.

LR chi square $(14)=124.01^{\star *} ;$ Prob $>$ chi-square $=0.000 ;-$ Log likelihood $=162.519$.

Nagelkerke R Square 0.466; Model correct prediction: $80.6 \%$.

** $P \leq 0.05$.

\section{Conclusions and Recommendations}

Farmers were aware of VietGAP requirements when farming beef cattle. Most of the farmers perceived that conforming to VietGAP while farming beef cattle required 'vaccinating cattle', followed by 'treating wastes daily to protect environment', 'using hygiene facilities to ensure food safety', 'putting cattle cages in the right position to protect environment' and 'choosing breeding from clear sources to ensure product traceability'.

Young farmers with higher education level, who possessed large number of cattle, owned large farm, had high income, and participated in credit and training programs are in a better position to adopt VietGAP than older and less educated farmers who owned small number of cattle, possessed small farm, had low income and did not 
Creative Commons User License: CC BY-NC-ND

Abstracted by: EBSCOhost, Electronic Journals Service (EJS),

Google Scholar, Journal Seek, Scientific Commons,

Food and Agricultural Organization (FAO), CABI and Scopus
Journal of Agricultural Extension

Vol. 24 (4) October, 2020

ISSN(e): 24086851; ISSN(Print); 1119944X

http://journal.aesonnigeria.org

http://www.ajol.info/index.php/jae

Email: editorinchief@aesonnigeria.org

take part in credit and training programs. Importantly, farmers who had contact with agricultural extension workers and who own ICT tools for marketing were better VietGAP adopters than those who did not communicate with the agricultural extension workers and did not possess ICT tools. Improving education, providing technical training and credit services, promoting the farmers' use of ICT tools for marketing and developing agricultural extension services for livestock farmers could be the way to facilitate the adoption of VietGAP by farmers.

\section{Acknowledgement}

Thank Hue University for its financial support in conducting this research.

\section{References}

Amekawa, Y., Ng, C. C., Lumayag, L. A., Tan, G. H., Wong, C. S., Abdulrauf, B., . . Liu, C. H. (2017). Producers' perceptions of public good agricultural practices and their pesticide use: The case of MyGAP for durian farming in Pahang, Malaysia. Asian Journal of Agriculture and Rural Development, 7(1), 1-16.

Annor, B. P., Mensah-Bonsu, A., \& Jatoe, J. B. D. (2016). Compliance with GlobalGAP standards among smallholder pineapple farmers in Akuapem-South, Ghana. Journal of Agribusiness in Developing and Emerging Economies, 6(1), 21-38.

Binh Dinh Statistical Office. (2020). Statitiscal Yearbook. Binh Dinh province: Binh Dinh Statistical Office.

Hoang, H. G. (2020). Exploring Vietnamese cereal smallholders' perceptions and adaptations to temperature and precipitation variability: implications for adaptation strategies. Local Environment, 25(8), 597-611. doi:10.1080/13549839.2020.1805599

Krause, H., Lippe, R., \& Grote, U. (2016). Adoption and income effects of public GAP standards: Evidence from the horticultural sector in Thailand. Horticulturae, 2(4), 121.

Laaksonen, S. (2018). Survey methodology and missing data: Tools and techniques for practitioners. New York: Springer.

Lippe, R. S., \& Grote, U. (2016). Determinants affecting adoption of GlobalGAP standards: A choice experiment in Thai horticulture. Agribusiness, 33(2), 242-256.

Loan, L., Pabuayon, I., Catelo, S., \& Sumalde, Z. (2016). Adoption of good agricultural practice (VietGAP) in the lychee industry in Vietnam. Asian Journal of Agricultural Extension, Economics \& Sociology, 8(2), 1-12.

Mukherjee, S. P., Sinha, B. K., \& Chatterjee, A. (2018). Statistical methods in social science research. Singapore: Springer.

Nguyen, L. T., Nanseki, T., \& Chomei, Y. (2019). The impact of VietGAHP implementation on Vietnamese households' pig production. Environment, Development and Sustainability. doi:10.1007/s10668-019-00543-w

Pedroso, R., Tran, D. H., Nguyen, T. M. H., Le, A. V., Ribbe, L., Dang, K. T., \& Le, K. P. (2017). Cropping systems in the Vu Gia Thu Bon river basin, Central Vietnam: On farmers' stubborn persistence in predominantly cultivating rice. NJAS - Wageningen Journal of Life Sciences, 80(2017), 1-13. 
Creative Commons User License: CC BY-NC-ND

Abstracted by: EBSCOhost, Electronic Journals Service (EJS),

Google Scholar, Journal Seek, Scientific Commons,

Food and Agricultural Organization (FAO), CABI and Scopus

http://eoi.citefactor.org/10.11226/v24i4
Journal of Agricultural Extension

Vol. 24 (4) October, 2020

ISSN(e): 24086851; ISSN(Print); 1119944X

http://journal.aesonnigeria.org

http://www.ajol.info/index.php/jae

Email: editorinchief@aesonnigeria.org

Rural and Agriculture Census. (2016). Report on the results of agriculture survey in 2016. Retrieved from https://www.gso.gov.vn/ItemPreview.aspx?/temID=14493

Sarkar, A. (2020). Role of livestock farming in meeting livelihood challenges of SC cultivators in India. Indian Journal of Human Development, 14(1), 23-41. doi:10.1177/0973703020923863

Srisopaporn, S., Jourdain, D., Perret, S. R., \& Shivakoti, G. (2015). Adoption and continued participation in a public good agricultural practices program: The case of rice farmers in the Central Plains of Thailand. Technological Forecasting and Social Change, 96(July 2015), 242-253.

Vu Thi, H., Nguyen Mau, D., \& Santi, S. (2016). Litchi farmers' preference for the adoption of Vietnamese good agricultural practices in Luc Ngan district, Vietnam. Journal of International Society for Southeast Asian Agricultural Sciences, 22(1), 64-76.

Wongprawmas, R., Canavari, M., \& Waisarayutt, C. (2015). A multi-stakeholder perspective on the adoption of good agricultural practices in the thai fresh produce industry. British Food Journal, 117(9), 2234-2249. 